\title{
Content and Accumulation of Oxalic Acid in Edible Species of Xanthosoma ${ }^{1}$
}

\author{
Dolores Cuebas de Escabi and Arturo Cedeño-Maldonado ${ }^{2}$
}

\begin{abstract}
A study was conducted to determine the content and accumulation of oxalic acid in tissues of three edible species of the genus Xanthosoma: $X$. caracu, $X$. atrovirens and $\chi$. violaceum. Oxalic acid determinations were performed by atomic absorption spectrophotometry. Significant differences were found among the species and tissues studied. Oxalate content was higher in leaf blade and petiole tissues and lower in the pulp of the cormels or rhizomes. Oxalate content in the rhizomes was lowest in $X$. violaceum and highest in $X$. caracu. Accumulation in different tissues was progressive and simultaneous with tissue development. No evidence of acid translocation was detected. Postharvest storage of rhizomes resulted in progressive reduction in oxalate content. In all samples analyzed throughout the study the oxalate content of cormels never exceeded $3 \%$ of their dry weight.
\end{abstract}

\section{INTRODUCTION}

The cocoyam, or tanier, an edible aroid of the genus Xanthosoma, locally known as "yautia", is an important food crop in tropical and subtropical countries. The starchy cormels, consumed in various ways, are an excellent source of carbohydrates and minerals, thus contributing to basic human dietary requirements (3). Their caloric value is about 535 calories per pound, compared to 570 for that of sweet potatoes and 385 for white potatoes (10). With the present worldwide food crisis, this crop could become important as an emergency subsistence food source because of its ability to grow and produce high yields under conditions where other starchy crops such as rice and potatoes cannot be grown. In Puerto Rico, cocoyams are second only to yams (Dioscorea spp.) in economic importance among the starchy food crops. In 1979-80 the production was estimated at $290,000 \mathrm{cwt}$ and its farm value was estimated at $\$ 6.5$ million (1).

Cocoyams and many other aroids are known to contain variable amounts of free oxalic acid and oxalates in their edible tissues. In other crops, such as spinach, the presence of these substances has been associated with nutritionally related health problems in man. Almost all members of the genus Xanthosoma contain minute, needle-like crystals of calcium oxalate, scattered throughout their tissues (13). These are known as "raphides" and are clustered in fascicles in special raphide cells (4). They are found in all parts of the plants: roots, tubers, rhizomes,

\footnotetext{
${ }^{\text {I }}$ Manuscript submitted to Editorial Board February 24, 1984.

${ }^{2}$ Former graduate student and Associate Professor, respectively, Department of Horticulture, University of Puerto Rico, College of Agricultural Sciences, Mayagüez, P. R.
} 
stems, leaves, inflorescences and fruits. These crystals are, in part, responsible for the acrid, burning sensation in the mouth when parts of the plants are chewed.

Oxalic acid is a dicarboxylic acid, which is relatively strong and moderately soluble in water. With calcium it forms a practically insoluble salt, a fact of considerable biological significance. The availability of calcium and magnesium in food is influenced by the presence of oxalic acid. In some cases, calcium in the diet is almost entirely unavailable in the presence of oxalic acid by the formation of the insoluble calcium oxalate, which is not assimilated by the organism. There has been considerable interest in studying the oxalic acid content of food in relation to its possible adverse influence on calcium utilization. The avoidance of high oxalate diets appears to be particularly important in case of calcium deficiency such as may occur in the elderly, in vitamin D deficiency, and in the malabsorption syndrome (7).

Oxalic acid accumulation is a characteristic of widespread distribution in the plant kingdom. In many species accumulation occurs as highly insoluble crystals of calcium oxalate, but it is also of wide occurrence as soluble or neutral acid salts or as free acid $(4,8,12)$. As crystals, it represents a considerable portion of the dry weight of some plant organs, more than $30 \%$ of shoot tissues in some succulents (4) and about $25 \%$ in cotyledons of spinach (6). The presence of calcium oxalate crystals in edible species such as spinach and red beet has attracted considerable attention from research workers because of its potentially deleterious effects.

The economic importance of cocoyam in Puerto Rico, and in the tropics, and the possible adverse effects of oxalic acid in the nutrition of humans and animals stimulated our interest in conducting a study to determine the content and distribution of oxalic acid in the tissues of different edible species of Xanthosoma.

\section{MATERIALS AND METHODS}

\section{PLANT MATERIALS}

Three varieties representing different species of Xanthosoma, Kelly, $X$. atrovirens; Vinola, $X$. violaceum; and Blanca, $X$. caracu were used for the studies on the content and accumulation of oxalic acid and oxalates in cocoyam. The seed material of the varieties Kelly and Vinola was obtained from a farm in Añasco, Puerto Rico, and that of the variety Blanca was obtained from the Isabela Substation of the Puerto Rico Agricultural Experiment Station. The planting material consisted of pieces of corms having at least two germinal buds and weighing about 85-114 $\mathrm{g}$ each. The seed was dipped in a fungicide solution containing 5 grams Benlate per gallon of water for 5 minutes before planting. 
Approximately 100 plants of each variety were planted February 13, 1979 , in rows spaced $90 \mathrm{~cm}$ between rows and $45 \mathrm{~cm}$ within the row in the Alzamora Farm in the Mayagüez Campus. The experimental plots were $9 \mathrm{~m}$ long and $4.5 \mathrm{~m}$ wide. Each plot contained approximately 100 plants.

Two months after planting, 8-8-13 fertilizer was applied at the rate of $57.0 \mathrm{~g}$ per plant. Weeds were handweeded. Samples consisting of different tissues (leaf, petiole and cormel) were collected and analyzed 4, 8 and 12 months after being planted.

\section{METHODOLOGY FOR DETERMINATION OF OXALIC ACID}

The standard AOAC method as modified by Franco and Krinitz (5) was used for the determination of oxalic acid. However, dried rather than fresh material was assayed. The procedure involved acid hydrolysis of extracts; oxalates were determined as oxalic acid. The following sequence was followed:

\section{Preparation of sample}

Fresh plant material was washed with tap water to remove soil and foreign matter. Fifteen-gram samples were weighed and dried in an aircirculating oven at $105^{\circ} \mathrm{C}$ for 8 hours. The dried samples were finely ground (mesh size \#6) and stored in airtight containers at room temperature until oxalate content was determined.

\section{Precipitation of oxalic acid}

A $2.5 \mathrm{~g}$ sample of the dry material was placed in a $250 \mathrm{ml}$ volumetric flask, to which approximately $190 \mathrm{ml}$ of water and $10 \mathrm{ml}$ of $6 \mathrm{~N} \mathrm{HCl}$ were added, to increase the acidity and prevent pectin retention. 'The flask was heated in a water bath for 1 hour, cooled to room temperature and filled to volume. The content of the flask was mixed and filtered through fast quantitative paper (Whattman No. 30 ) $;^{3}$ the first 10 -ml filtrate was discarded.

About $25 \mathrm{ml}$ of the filtrate was pipetted into a $50 \mathrm{ml}$ Erlenmeyer flask to which $5 \mathrm{ml}$ of tungstophosphoric acid reagent was added, mixed and allowed to stand for about 5 hours. The solution was then filtered through the relatively fast quantitative paper (Whattman No. 30), and $20 \mathrm{ml}$ of the filtrate was pipetted into a $50 \mathrm{ml}$ conical centrifuge tube, to which ammonium hydroxide was added until a $\mathrm{pH}$ of 4-4.5 was obtained.

\footnotetext{
${ }^{3}$ Trade names in this publication are used only to provide specific information. Mention of a trade name does not constitute a warranty of equipment or materials by the Agricultura] Experiment Station of the University of Puerto Rico, nor is this mention a statement of preference over other equipment or materials.
} 


\section{Precipitation of calcium oxalate}

About $5 \mathrm{ml}$ of a buffered solution, $\mathrm{pH} 4.5$, (containing calcium chloride, acetic acid and sodium acetate) was added to the filtrate in the centrifuge tubes and the filtrate was stirred with a glass rod which was subsequently rinsed into the tube with a small stream of water. The tubes were allowed to stand overnight. The following day the tubes were centrifuged for 15 minutes at $1700 \mathrm{r} / \mathrm{min}$ to compact the precipitate. The supernatant liquid was decanted and the precipitate was washed with a fine jet stream of 20 $\mathrm{ml}$ filtered cold liquid wash to completely break the precipitate into a fine suspension. The centrifugation and decanting steps were repeated to assure complete washing of the precipitate.

Determination of oxalic acid and oxalate content by atomic absorption spectrometry

Preparation of aliquots to be read in the spectrophotometer. The content of the centrifuge tube was quantitatively transferred to a $10 \mathrm{ml}$ volumetric flask, which was filled to volume with $10 \% \mathrm{H}_{2} \mathrm{SO} 4$, from this solution; 2 $\mathrm{ml}$ were pipetted into a $50 \mathrm{ml}$ volumetric flask containing $10 \mathrm{ml}$ lanthanum solution and diluted to volume with water. Then $15 \mathrm{ml}$ of this solution was transferred to a $25 \mathrm{ml}$ volumetric flask containing $2 \mathrm{ml}$ of lanthanum solution and diluted to volume with water. This solution was used for the assay of calcium as calcium oxalate in the atomic absorption spectrophotometer.

Preparation of calcium standards for calibration of atomic absorption instrument. The calcium standards were prepared according to the following procedure: $0,2,4,6,8,10$ and $12 \mathrm{ml}$ of calcium working solution (5) was pipetted into $50 \mathrm{ml}$ volumetric flasks. Then $10 \mathrm{ml}$ of lanthanun solution was added to each flask and diluted to volume with water before being read in the Atomic Absorption Spectrophotometer.

Determination of oxalic acid and oxalates. A Jarell Ash Atomic Absorption Spectrophotometer Model 82-528 was used to determine the calcium content of samples. The absorbance $\left(\mathrm{A}^{\circ}\right)$ of sample and standard solutions was determined by taking two readings of standard solutions before and after sample readings. The oxalate content was determined by plotting $\left(\mathrm{A}^{\circ}\right)$ against, $\mu \mathrm{g}$ of oxalate as calcium oxalate per ml. Calcium determinations in sample included the free acid plus its oxalate salts present in the plant material.

\section{RESULTS AND DISCUSSION}

The presence of calcium oxalate crystals in members of the genus Xanthosoma, such as cocoyam, is well documented $(13,14)$, but there is no information of its content and distribution in different tissues of this 
important food plant. Table 1 provides data from mature plants of cultivars representing the three different species of Xanthosoma studied. There was considerable variation in oxalate content among the different tissues assayed. Leaf and petiole tissues showed the highest content and the pulp of cormels showed the least. Values for the pulp of cormels, the edible portion, were in the range of 1 to $2 \%$, approximately three times less than the values obtained for the petiole and leaf tissues. Although the oxlate content in leaf and petiole tissue might be considered high, it is only about one half of that found in some varieties of spinach (9). Some spinach varieties have been reported to contain as much as $15 \%$ oxalate (6).

There were significant differences in oxalate content among species. This was particularly important in the case of the edible cormels. Vinola ( $X$. violaceum) followed by Kelly ( $X$. atrovirens) showed the lowest

TABLE 1.-Total content of oxalic acid in the tissues of three varieties of Xanthosoma at harvest time

\begin{tabular}{lccc}
\hline \multirow{2}{*}{ Tissue } & \multicolumn{3}{c}{ Varieties $^{\mathrm{i}}$} \\
\cline { 2 - 4 } & Blanca & Kelly & Vinola \\
\hline Pulp of cormel & $1602 \mathrm{a}^{2}$ & $1186 \mathrm{~b}$ & $1027 \mathrm{c}$ \\
Peel of cormel & $3592 \mathrm{a}$ & $1541 \mathrm{~b}$ & $2938 \mathrm{a}$ \\
Petiole & $6981 \mathrm{a}$ & $5252 \mathrm{~b}$ & $4975 \mathrm{bc}$ \\
Leaf blade & $6574 \mathrm{a}$ & $5965 \mathrm{a}$ & $7048 \mathrm{a}$ \\
\hline
\end{tabular}

\footnotetext{
'Values are expressed in $\mathrm{mg} / 100 \mathrm{~g}$ of dry weight.

${ }^{2}$ Means in columns followed by the same letter do not differ significantly at the $5 \%$ probability level.
}

content. Levels ranged between 1 and $2 \%$, with Blanca (X. caracu) showing the highest levels. Although there is no direct reference in the literature, apparently tissues containing less than $2 \%$ oxalate should be considered safe for human consumption. The fact that there are significant differences among species provides the basic ground for establishing breeding programs for developing low oxalate cultivars.

Figure 1 shows data on the levels of oxalate in different tissues at different plant ages. In general terms the concentration of oxalate in all tissues increased as the tissues developed. It is apparent from the results that accumulation in each tissue is independent; that is, there are no clear-cut patterns of translocation from one tissue to another as has been reported in other species (17). The data support studies on the biosynthesis of oxalic acid pointing to the fact that this acid can be synthetized in situ in different plant organs such as leaves, stems and storage organs. Studies also have demonstrated oxalic acid biogenesis from different 


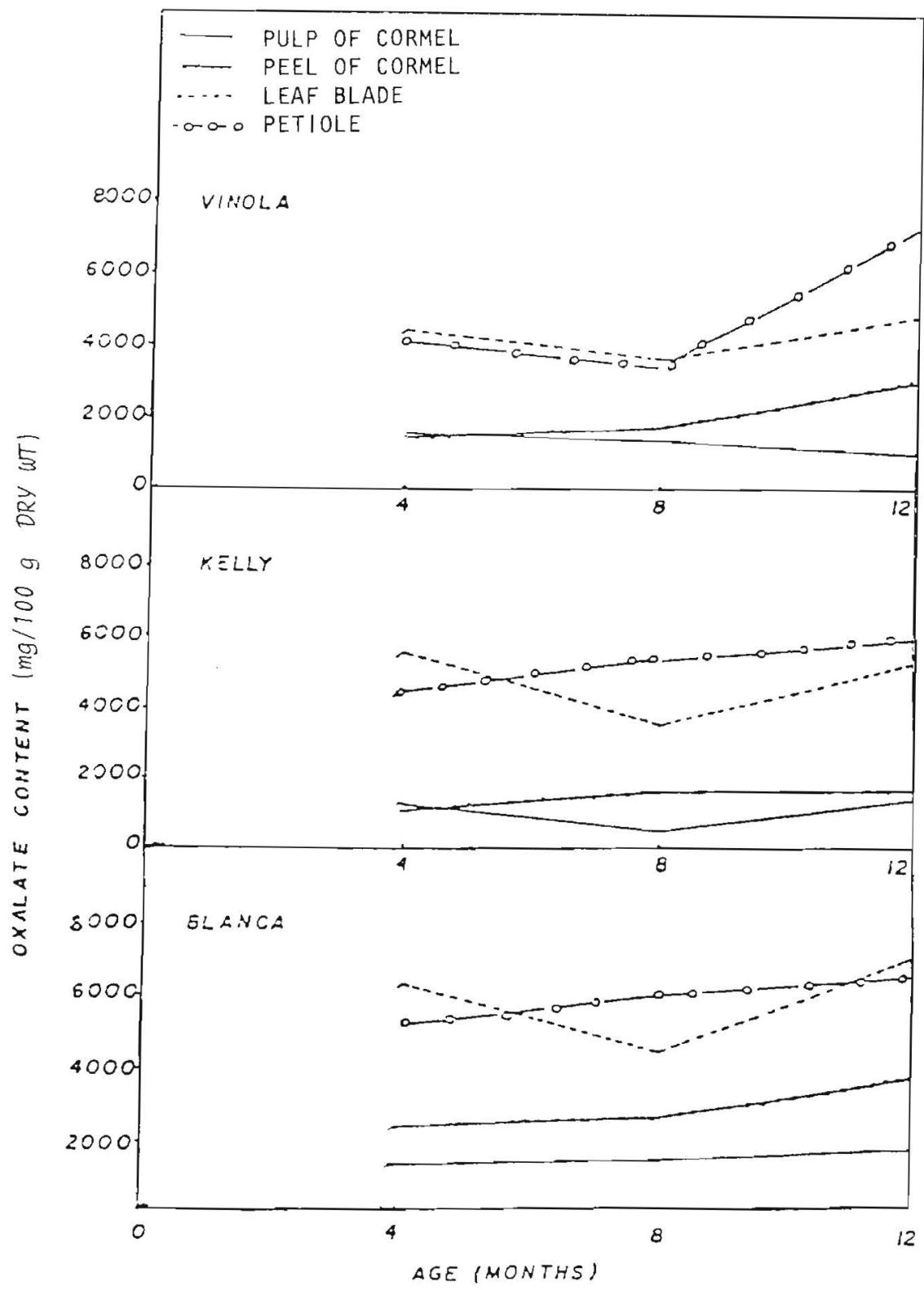

FIG. 1.-Levels of oxalic acid in different tissues of three varieties of Xanthosoma from planting to maturity. 
substrates such as glyoxilic, ascorbic and oxalacetic acids $(2,11,16)$. In addition, photosynthetic $\mathrm{CO}_{2}$ fixation into oxalic acid has been demonstrated in leaf tissues of red beet and spinach (2). Apparently, all tissues of Xanthosoma have an inherent ability to synthetize oxalates.

Table 2 shows changes in oxalic acid occurring during postharvest storage of cormels. Significant postharvest reduction in oxalates occurred in the cormels during storage. Reduction was more marked in Xanthosoma atrovirens, although the tissues in this species had a higher initial oxalate content.

The mechanism of oxalate breakdown in plants is largely unknown although enzymatic oxidation of oxalic acid has been demonstrated in cell free preparations of bougainvillea (15). The progressive reduction in oxalate content during postharvest storage has important practical implications since in addition to being cooked immediately, cormels are frequently stored for some time before being consumed. In all samples analyzed throughout this study the oxalate content found in the edible

TABLE 2.-Changes in oxalic acid contents in cocoyam cormels during post harvest storage

\begin{tabular}{clrrr}
\hline \multirow{2}{*}{$\begin{array}{c}\text { Length of } \\
\text { storage }\end{array}$} & \multicolumn{4}{c}{ Varieties $^{1}$} \\
\cline { 2 - 5 } & Kelly & Percent & Vinola & Percent \\
\hline Days & & & & \\
15 & $2693^{2}$ & 100 & 1108 & 100 \\
30 & 1757 & 65 & 902 & 81 \\
45 & 1358 & 50 & 783 & 70 \\
& 572 & 21 & 334 & 30 \\
\hline
\end{tabular}

'Data represent mean values of three replications.

${ }^{2}$ Values are expressed in $\mathrm{mg} / 100 \mathrm{~g}$ dry weight.

pulp of the cormel never exceeded 3\%. This value is lower than that found in other extensively used vegetables such as spinach and red beet $(6,9,12)$; thus, there should be no reason for restricting the use of cocoyam (or tanier) as human food.

\section{RESUMEN}

Se hizo un estudio para determinar el contenido y acumulación de ácido oxálico en tejidos de tres especies comestibles del género Xanthosoma: $X$. caracu, X. atrovirens y X. violaceum. Las determinaciones se hicieron con espectrofotometría de absorción atómica. Se encontraron diferencias significativas entre las distintas especies y los tejidos estudiados. EI contenido en oxalato fue mayor en tejidos del peciolo y la lámina de la hoja y menor en la pulpa de los rizomas y cormelos. El contenido en oxalato de los rizomas fue menor en la yautía vinola ( $X$. violaceum) y mayor en la yautía blanca ( $X$. caracu). La acumulación en los distintos tejidos fue 
progresiva a medida que los tejidos se desarrollaban; no se encontró evidencia de traslado del ácido. En rizomas almacenados el contenido en oxalato bajó progresivamente. En ninguna de las muestras el contenido en oxalato del rizoma fue mayor de $3 \%$ del peso seco.

\section{LITERATURE CITED}

1. Annonymous. 1980. Commonwealth of Puerto Rico Department of Agriculture. Facts and Figures on Puerto Ricos Agriculture. 1979-80. Santurce, Puerto Rico.

2. Chang, Chi-Cheng and Beevers, H., 1968. Biogenesis of Oxalate in Plant Tissues, Plant Physiol. vol 43:1821-28.

3. Coursey, D. G. and Haynes, P. H., 1970. Root Crops and Their Potential as Food in the Tropics, World Crops. July/August pp. 261-65.

4. Dye, W. B., 1956. Method of Analyzing for Plant Oxalate Content, Weeds 4:55-60.

5. Franco, W. and Krinitz, B., 1970. Determination of Oxalic Acid in Foods, Assoc. Off. Agric. Chem. 56:164-66.

6. Kitchen, J. W., Burns E. E., and Perry, B. A., 1963. Calcium Oxalate Content of Spinach (S. oleraecae) Proc. Am. Soc. Hortic. Sci. 84:441-45.

7. Kohman, E. F., Oxalic Acid in Foods and its Behavior and Fate in the Diet, J. Nutr. 18:233-46.

8. Krishnanmurty, P. V., 1961. Oxalate content in a Number of Indian Edible Species, J. Indian Chem. Soc. 18:201.

9. Lambeth, V. N., Regan, W. S., Brown, J. R. and Blevins, D. G., 1969. Spinach Cation and Oxalate Contents and Their Interactions as Influenced by Fertilization, Food Technol. 23:937-76.

10. Morton, J. F., 1972. Cocoyam (X. caracu, $X$. atrovirens and $X$. nigrium), Ancient Root and Leaf Vegetables Gaining in Economy Importance. Fla. State. Hort. Soc. Proc. 85:85-90.

11. Nuss, R. F. and Loewus, F. A., 1980. Further studies on Oxalic Acid Biosynthesis in Oxalate Accumulating Plants, Plant Physiol. 61:590-92.

12. Oke, O. L., 1969. Oxalic Acid in Plants and Nutrition, Indian Med. Res. 52:282-83.

13. Sakai Williams, S. and Hanson, M., 1974. Mature Raphide and Raphide Idioblast Structure in Plants of the Edible Aroid Genera Colocasia, Alocasia, and Xanthosoma. Am. Bot. 38:739-48.

14. —__ and Jones, R. C., 1972. Raphides with Barbs and Grooves in Xanthosoma sagittifolium (Araceae), Science. 78:314-15.

15. Srivastava, S. K. and Krishnan, P. S., 1962. An Oxalic Acid Oxodase in the Leaves of Bougainvillea spectabilis. Biochem. J. 85:33-8.

16. Stal, S. N. and Sen. S. P., 1979. The Photosynthetic Production of Oxalic Acid in Oxalis corniculata. Plant Cell Physiol. 11:119-28.

17. Vek, H. L. and Adolph, W. H., 1938. Oxalic Acid Content of Some Vegetables, Chin. J. Physiol. 13:209-22. 